As its etymology implies, the term "atonement" (at-one-ment) denotes the restored state of fellowship between God and humanity_God and humanity being "at one." In the early Church a variety of categories - such as redemption, forgiveness, revealed knowledge, purification or expiation, and propitiation - contribute to making "atonement." The word is, therefore, used here with two caveats. First, while the term itself was unavailable to early Christians, the idea that, because of Jesus, God and humanity can dwell together in harmony and close proximity is central to early Christianity. The notion is so ubiquitous and fundamental that the survey here can only trace major contours and note illustrative examples. Second, while the various concepts noted above can be explored in a given ancient text independently of one another, they could equally intermingle and/or be treated as concurrent. This study identifies distinct categories, but it would be a mistake to assume that any given author or text necessarily conceived of one category as mutually exclusive of others. Often one finds multiple conceptions in play. Importantly, the various concepts invoked largely depend upon the human problem that Jesus solves (see Tuckett, 1992, 518). To speak about atonement in early Christianity is, therefore, to speak about the variety of ways that various early Christians conceived of Jesus and his work as negotiating the variety of problems that prevent humanity from being "at one" with God. We here examine four major categories of problem and their corresponding solutions: sin, enslavement to death and the Devil, the fallen human condition, and false knowledge. Amidst the diversity, it is clear that in the Patristic era both the divinity and the humanity of Jesus were viewed as making essential contributions to atonement.

\title{
Sin and Atonement
}

One of the most pervasive problems that early Christians envisioned Jesus solving was that of sin. Interest in sin flowed directly from the movement's Jewish and biblical taproot, which provided many of the metaphors for conceiving of the problem and its solutions. Four of the most significant metaphors are: sin as impurity/stain, sin as offense, sin as weight/burden, and sin as debt/enslavement. Each of these has a corresponding solution. Impurity needs to be purged by rituals such as washing and/or blood sacrifice. Restitution, repentance, and sacrifice can deal with an offense and its corresponding guilt. The burden needs to be lifted or carried away, as in the scapegoat ritual of the Day of Atonement. Debt requires payment in appropriate currency. All of these conceptions of sin and their solutions are directly related to Jesus' person and work by early Christians.

The biblical and Jewish practices of particular sacrificial and washing rituals, as well as confession and expressions of genuine repentance were central to obtaining purification and for maintaining peace with God. Links between these practices and Jesus are already evident in the earliest Christian texts collected in the New Testament (for example, Matt 26:28; Luke 24:47; 
John 1:29; Acts 2:38; 3:19; 22:16; Rom 3:25; Col 1:20-22; Heb 1:3; 2:17; 9:26; James 5:16; 1 John 1:9; 2:2), but they find substantial development in the Patristic era.

A diverse number of ritual ideas are applied to Jesus to show how he dealt with the problem of sin. Christian baptism is viewed as a means of washing away or forgiving sins (Barn. 11.1-11; Justin 1 Apol. 61; Dial. 14.1; Irenaeus Epid. 3). The notion that Jesus died as the sacrificial victim of a sin offering/“for sins" is ubiquitous. Ignatius, while not explicitly calling Jesus' death a sacrifice, appears to assume this notion when conceiving of his own death sacrificially (Rom. 4-6; Daly, 1978b, 320). 1 Clem. speaks of the pouring out of Jesus' blood as enabling repentance $(6.4 ; 12.7) .1 \mathrm{Clem}$. further highlights the importance of repentance for cleansing the stain of sin (7.5-8.5; see also 2 Clem. 8). Barn. 5.1 links Jesus' sprinkled blood with forgiveness of sin (similarly $7.3 ; 12.1$ ). Other 2nd century sources connect Jesus' death and awaited return with the two goats of the Day of Atonement (Barn. 7.3-11; Justin Dial. 40.4; Tertullian Marc. 3.7.7-8). The idea that Jesus' blood purifies believers is clearly attested (Justin Dial. 54.1; Irenaeus Epid. 57). Jesus' blood also rescues people from the power of death like the blood of the Passover lambs (Justin Dial. 40.1; 111.3-4; Irenaeus Epid. 25; Tertullian Marc. 4.40; 5.7; Melito Pascha $31-32,67)$. Origen argues that Jesus' flesh was sacrificed for sin. Thus, his death enabled the purification and destruction of sin because sin, which Jesus bore in his body, was condemned in the death of his flesh (Hom. Rom. 6.12). Ephrem likens the cross to a censer where Jesus' blood, like incense, was offered to God (Hom. Our Lord, 9.2). Notably, too, the suffering and death of Jesus, as well as his burial and resurrection (Irenaeus Epid. 72), could be identified as the means of bringing God and humanity together without ritual ideas being explicitly invoked. Ignatius identifies the cross as the central mechanism that carries humanity up to God (Eph. 9.1; similarly, Irenaeus Epid. 45). Such reflection on the sacrificial significance of Jesus' death only continues to develop in later centuries.

Another link between Jesus' atoning work and Jewish sacrificial concepts lies in the identification of Jesus as both the great high priest and as the sacrifice offered to God. When reflecting on Jesus' high priesthood, special attention is often directed to the particular contribution that Jesus' humanity makes toward effecting atonement. Justin points to Jesus' high-priestly service as the means for removing the stain of sin and providing forgiveness (Dial. 116.1-3). Irenaeus implies that Jesus' ascension marked the presentation of his humanity as a sacrificial offering to God (Haer. 3.19.3; cf. Haer. 3.17.3). The ascended Jesus now intercedes for his people and thereby redeems them (Epid. 88). He also describes Jesus' high-priestly work in terms of propitiating God and releasing exiled humanity from condemnation to regain their inheritance without fear (Haer. 4.8.2). Origen holds that Jesus' blood was sprinkled "for sins" on earth when he died in Jerusalem. He also argues that, because of Jesus' resurrection and ascension, Jesus serves as the high priest who sprinkled his blood as a spiritual offering at the altar in heaven (Hom. Lev. 1.3.19-33; 7.1.110-118, 2.37-57). Through this dual-sacrificial activity Jesus made peace on earth, by defeating the evil powers, and in heaven, by bringing 
humanity in his own person back into God's presence (Young, 1979, 175-179). Expanding on the latter point, Origen makes an analogy to the high priest's actions on the Jewish Day of Atonement (see Leviticus 16), especially as interpreted in the Epistle to the Hebrews. Just as the earthly high priests entered the holy of holies once a year to intercede for the people while offering the sacrificial blood for forgiveness and purification, so Jesus rose from the dead and ascended into heaven there to offer himself once to God to make propitiation and intercede continually for his people at the heavenly altar (Hom. Lev. 7.2.37-57; 9.5.51-112; see Moffitt, 2017). The idea that Jesus presented himself - that is, his resurrected humanity - to God in heaven as a sacrificial offering continued to be influential, especially in the East (though see also Hippolytus, Noet. 4). Gregory of Nazianzus speaks of the "sacrifice of the resurrection" (Letter 171). Theodoret of Cyrus, commenting on Heb 8:1-4, argues that Jesus assumed human nature in order to offer that nature to God on behalf of the rest of humanity when he ascended into heaven (Comm. Omn. S. Pauli Epist. [PG 82, 736]). Regarding Heb 9:24-26 he claims that Jesus, as the great high priest, appeared as a human being before God in the tabernacle of heaven to present himself as a sacrifice, his perfected humanity dealing decisively with $\sin (P G 82,745)$. Narsai speaks of Jesus' ascension with his resurrected body of dust as his entry into the holy of holies to serve as high priest. There he appeared before God to make atonement by offering the sacrifice of himself (Hom. Feast Day Ascen. 81-84; 200-210).

The idea that the burden of sin was removed by Jesus' suffering and death is also prominent. The so-called "servant songs" of Isaiah are important in this regard (1 Clem. 16.4, 12, 14; Pol. Phil. 8.1; Origen Hom. Rom. 6.12). Explicit comparisons between Jesus and the scapegoat ritual further develop this idea. Origen identifies Jesus as the one who led the "lot of the scapegoat," that is the powers of the Devil, sin and death, off into the wilderness of hell when he died (Hom. Lev. 9.5.26-33, 42-50). Somewhat differently, Cyril of Alexandria argues that Jesus bore sins away like the scapegoat when, after his resurrection, he carried them off to heaven as part of his offering to the Father (Glaph. Lev. [PG 69, 588-589]).

The notions that Jesus is the redeemer who pays off the debt owed by sinners, or who offers himself in place of those who are rightfully held in bondage because of their sin, are also common (see further Enslavement and Atonement below). Jesus' own life and/or suffering can be seen as given in exchange for others (1 Clem. 49.6; 55.1-2; Pol. Phil. 9.2; Diogn. 9.2-6; Irenaeus Haer. 5.1.1; Cyril of Alexandria, Letter 41; see Lyonnet and Sabourin, 1970, 197-198). Irenaeus envisions Jesus' suffering as taking away the punishment rightly due to sinners (Epid. 69). He also identifies the sacrifice of Isaac as pointing to the sacrifice of Jesus for redemption (Haer. 4.5.4). He argues as well that Jesus' suffering provided merit or credit that can be used to pay off the debts of sinners (Haer. 5.17.3; see also Anderson, 2009, 121-132). Even the individual Christian can make a contribution. The work of one's hands, suffering for the "the name," and almsgiving are among the activities explicitly identified as paying or ransoming for 
one's $\sin$ (2 Clem. 16.4; Did. 4.5-8; Barn. 19.10-11; Pol. Phil. 10.2; Herm. Sim. 9.28.3-7; see Garrison, 1993, 76-142; Anderson, 2009, 152-188).

\section{Enslavement and Atonement}

While related to the problem of sin, especially conceived of as debt, reflection on how Jesus provides the solution to humanity's enslavement to death and the Devil tends to focus on the way that Jesus frees humanity from these powers to restore fellowship with God. Here, too, both Jesus' divinity and humanity are essential for humanity's liberation. Jesus' redeeming work is viewed in terms of his leading humanity out of slavery to death and the Devil (Barn. 14.5-6; 16.9). Jesus' birth is identified by Justin as liberating humanity from demonic power (Dial. 78.9). On the basis of texts such as Eph 6:12 and Col 2:14-15, many thought in terms of Jesus' death serving as payment to or satisfaction for the legal claim of the powers of sin, death, and the Devil. This so-called "ransom theory" is already present in the 2nd century. Irenaeus explains that humanity fell into debt to death and into the power the Devil when Adam and Eve disobeyed. Because the Word of God was immortal, he had to become human for only as a human being could he bind the strong man, defeat death, and rise again to free the rest of humanity from sin and death and restore union with God (Haer. 3.18.6-7; 5.21-23; Epid. 31, 37-39). Tertullian clearly speaks about Jesus' death and blood as payment for humanity's debt. Because of Jesus' death, hell and the evil angels had to give up their rightful claim on humanity (Fug. 12). Athanasius also argues that the incarnation of the immortal Word of God was necessary to free humanity because only as a human being could the Word die, void death's legal claim on humanity, and free humanity to the life of resurrection (Inc. 6-10). These ideas are expanded to include notions of the humanity of the Word serving as bait. The Devil thought he could defeat Jesus by killing his humanity, but was tricked and "hooked" since Jesus' divinity ensured that his humanity would not remain subject to death (Gregory of Nyssa Or. Cat. Mag. $22-24,26$ ). Jesus' humanity is also portrayed as concealing the divinity of the Word of God like a medicine. Death unwittingly consumed the medicine only to induce the vomiting out of those whom it had previously devoured (Ephrem Hom. Our Lord 3.1-4).

The Human Condition and Atonement

The "recapitulation theory," prominent in Irenaeus, highlights the need for every phase of human existence to be restored in order for God and humanity to dwell together. Again, both the divinity and humanity of Jesus contribute to this restoration. The entire sweep of the incarnation, from Jesus' conception in Mary's womb through to his heavenly ascension and session, is seen as the means of gathering humanity together for redemption, as well as of healing every stage of fallen human existence. Irenaeus identifies the totality of the incarnation as solving the conjoined problems of sin, mortality, and the corruption of the human body. In his incarnation the Word passed through every period of human life in order to defeat death and restore fellowship 
between God and humanity (Haer. 3.18.7). In this way Jesus returned the image of God, which Adam had lost, to humanity and advanced humanity to perfection, making the human body immortal and incorruptible (Haer. 3.18.1, 7; 19.1, 3; 4.38.1-4; 5.1.3; Epid. 31; Daly, 1978a, 9394). The idea that the Word of God became a human in order that humanity might become like the Word of God anticipates the later doctrine of deification (Russell, 2004, 105-110).

Knowledge and Atonement

Another major category of problem that separates God and humanity is that of ignorance or false knowledge, particularly as these are a major source of disobedience. In arguing with the Gnostics it becomes clear that for the proto-Orthodox, this conception also highlights the contributions of both Jesus' humanity and divinity. Thus, Jesus brings right knowledge in his teaching, as well as, by virtue of his divinity, making God and his ways visible in his human body to humanity. Texts like Matt 11:27 and John's Gospel, especially its depiction of Jesus as the Logos and the light shining in the darkness, are particularly influential in this regard. Ignatius identifies the birth of Jesus as an event that destroyed ignorance, freeing humanity from the grip of magic and the bondage of evil. The manifestation of God in a human manner threw the realm of death into chaos (Eph. 19). Even those who criticized the Gnostics thought that true knowledge was essential for restored fellowship with God. For Irenaeus sin stains the flesh, while false knowledge and teaching stain the soul. Both keep humanity away from God and lead to death (Epid. 2). Right teaching illuminates the path the believer should walk to have union with God (Epid. 1). He identifies the cross as the tree that destroys the knowledge of evil while revealing the knowledge of good (Epid. 34). The incarnation provides salvation by making knowledge of the invisible God known to humanity in the visible Jesus (Haer. 4.7.1-7). For Clement of Alexandria, Christ, whom he calls the Pedagogue (Paed. 1.1), imparts the true knowledge that leads humanity to God. As God, the Word forgives our sin. As the human being Jesus, the Word trains us not to sin (Paed. 1.3). Only the Christian is truly able to follow Socrates' advice to "know thyself," and knowledge of God even enables deification (Paed. 3.1; see also Hippolytus Haer. 10.30). Tatian identifies the acquisition of the knowledge of God as the way in which the soul, illumined by the Logos, becomes immortal, is united with the Spirit of God, and is enabled to be united with God (Or. 13, 15).

\section{Modern Discussion}

A number of significant studies on or relating to some aspect of atonement in the Patristic era have been written in the last hundred years (for example, Rashdall, 1919; Lyonnet and Sabourin, 1970; Daly, 1978b; Young, 1979; Anderson, 2009). While dated, Gustaf Aulén's Christus Victor (1931) has been among the most influential. Aulén challenged the "Latin idea" of atonement (especially as exemplified by Anselm) and its suggestion that Jesus' sacrifice effected atonement as an offering from humanity to God. He argued that God's victory over the opposing powers 
through the death and resurrection of Christ was entirely God's own work, and that this was the dominant "classic idea" of the atonement in the Patristic era. Aulén helpfully brought an undervalued or demythologized aspect of the atonement in early Christianity back into view. Nevertheless, his attempt to remove from early Christianity the idea that Jesus' humanity contributed to effecting atonement does not fit the evidence. Early Christian conceptions of Jesus as the high priest in heaven, for example, particularly highlight the essential contribution of his humanity in procuring atonement.

Bibliography

Anderson, G.A., Sin: A History, New Haven, 2009.

Aulén, G. Christus Victor: An Historical Study of the Three Main Types of the Idea of Atonement, trans. A.G. Herbert, London, 1931.

Daly, R.J., The Origins of the Christian Doctrine of Sacrifice, Philadelphia, 1978a.

Daly, R.J., Christian Sacrifice: The Judaeo-Christian Background Before Origen, The Catholic University of America Studies in Christian Antiquity 18, Washington, D.C., 1978b.

Garrison, R., Redemptive Almsgiving in Early Christianity, Journal for the Study of the New Testament Supplement Series 77, Sheffield, 1993.

Lyonnet, S. and Sabourin, L., Sin, Redemption, and Sacrifice: A Biblical and Patristic Study, Analecta Biblica 48, Rome, 1970.

Moffitt, D.M., “Jesus' Heavenly Sacrifice in Early Christian Reception of Hebrews: A Survey." Journal of Theological Studies 68 (2017): 46-71.

Rashdall, H., The Idea of Atonement in Christian Theology, Bampton Lectures 1915, London, 1919.

Russell, N., The Doctrine of Deification in the Greek Patristic Tradition, Oxford Early Christian Studies, Oxford, 2004.

Tuckett, C.M., “Atonement in the NT," in: D.N. Freedmen, ed., The Anchor Bible Dictionary, vol. 1, New York, 1992, 518-522.

Young, F.M., The Use of Sacrificial Ideas in Greek Christian Writers from the New Testament to John Chrysostom, Patristic Monograph Series 5, Philadelphia, 1979.

David M. Moffitt 